\title{
Gene Expression in a Subpopulation of Luteinizing Hormone- Releasing Hormone (LHRH) Neurons Prior to the Preovulatory Gonadotropin Surge
}

\author{
Tarja Porkka-Heiskanen, ${ }^{1}$ Janice H. Urban, ${ }^{2}$ Fred W. Turek, ${ }^{2}$ and Jon E. Levine ${ }^{2}$ \\ 'Department of Physiology, University of Helsinki, Helsinki, Finland and ${ }^{2}$ Department of Neurobiology and Physiology, \\ Northwestern University, Evanston, Illinois 60208
}

Gene expression in luteinizing hormone-releasing hormone (LHRH) neurons was analyzed during the periovulatory period to (1) characterize temporal patterns of LHRH gene expression and their relationship(s) to gonadotropin surges, and (2) determine if any such changes are uniform or dissimilar at different rostrocaudal levels of the basal forebrain. The number of neurons expressing mRNA for the decapeptide, and the relative degree of expression per cell were analyzed using in situ hybridization and quantitative image analysis. Rats were killed at 1800 hr on metestrus (Met), $0800 \mathrm{hr}, 1200 \mathrm{hr}, 1800 \mathrm{hr}$, and $2200 \mathrm{hr}$ on proestrus (Pro), or $0200 \mathrm{hr}, 0800 \mathrm{hr}$, and $1800 \mathrm{hr}$ on estrus (E; $n=5-6$ rats/ group). All sections were processed for LHRH mRNA in a single in situ hybridization assay. Sections were atlas matched and divided into four rostrocaudal groups for analysis: vertical limb of the diagonal band of Broca (DBB), rostral preoptic area/organum vasculosum of the lamina terminalis (rPOA/OVLT), medial preoptic area (mPOA), and suprachiasmatic/anterior hypothalamic area (SCN/AHA). Plasma LH and FSH levels from all animals were analyzed by RIA. The labeling intensity per cell was similar among all time points at all four rostrocaudal levels. The number of cells expressing LHRH mRNA, however, varied as a function of time of death during the estrous cycle, and this temporal pattern varied among the four anatomical regions. At the level of the mPOA, the number of cells was highest at $1200 \mathrm{hr}$ on Pro, and then declined and remalned low throughout the morning of E. At the level of the rPOA/OVLT, the greatest number of LHRH neurons was noted later in Pro, at $1800 \mathrm{hr}$, dropping rapidly to lowest numbers at $2200 \mathrm{hr}$. No significant changes in LHRH cell number occurred at the DBB or SCN/AHA levels. At all anatomical levels, the secondary surge of FSH was unaccompanied by any change in the number of neurons expressing LHRH mRNA. These data demonstrate that (1) the number of detectable LHRH mRNA-expressing cells fluctuates during the periovulatory period and (2) peak numbers of LHRH-expressing cells are attained in the MPOA before the onset of the LH surge and before peak LHRH cell numbers are seen at more rostral levels. A model is proposed in which

\footnotetext{
Received July 13, 1993; revised Feb. 28, 1994; accepted Mar. 9, 1994.

This work was supported by NIH Grants R01-HD20677, P01-HD21921, K04HD00879 (RCDA to J.E.L.), P30-HD28048, and Academy of Finland (T.P.-H.).

Correspondence should be addressed to Dr. Jon E. Levine, Department of Ncurobiology and Physiology, 2153 Sheridan Road, Evanston, IL 60208.

Copyright (C) 1994 Society for Neuroscience $0270-6474 / 94 / 145548-11 \$ 05.00 / 0$
}

gene expression in this subpopulation of LHRH neurons may be activated by preovulatory estrogen secretion and acutely reduced following the proestrous surge of progesterone.

IKey words: luteinizing hormone-releasing hormone (LHRH), luteinizing hormone (LH), gene expression, in situ hybridization]

The preovulatory surges of LH and FSH are initiated by an abrupt increase in the neurosecretion of luteinizing hormonereleasing hormone (LHRH) (Sarkar et al., 1976; Levine and Ramirez, 1982), an event that has been clearly linked to activation of LHRH neurons in the preoptic area (Lee et al., 1990, 1992). It remains unclear, however, what functional relationship may exist between LHRH secretion and LHRH biosynthesis during this same period. Gene expression may be augmented in anticipation of the surge, coactivated along with the release process, or increased subsequent to LHRH release. Such changes in LHRH gene expression could serve to provide an augmented releasable pool of the decapeptide for production of the LHRH surge, or to replenish LHRH stores following the LHRH release episode. Periovulatory LHRH gene expression, moreover, may be altered in at least two different ways: the rate of LHRH gene expression may be changed similarly within an entire group of LHRH neurons, or LHRH gene expression may be induced during the preovulatory period in subpopulations of neurons which, at other times, express the gene at very low levels. Immunocytochemical studies (Hiatt et al., 1992) have, in fact, revealed that subpopulations of LHRH neurons exist in which production of the decapeptide may be differentially induced during proestrus, a finding that is also suggested by the observation that the overall number of LHRH-expressing cells is increased as the LH surge reaches its apex (Park et al., 1990). To date, however, complete temporal patterns of periovulatory LHRH gene expression have not been analyzed and compared among different regions of the brain in the same study.

The present study closely examines and compares periovulatory patterns of LHRH gene expression in four separate regions of the basal forebrain, so as to determine their respective temporal relationships with gonadotropin surges. Our primary aim was to determine for the first time if the number of LHRH mRNA-expressing neurons and/or the rate of LHRH gene expression are differentially altered at different rostrocaudal levels in association with the generation of the primary gonadotropin surge. Our results reveal several surprising aspects of periovulatory LHRH gene expression, the first being that it is primarily the number of neurons expressing detectable mRNA for the 
decapeptide, rather than a graded shift in the biosynthetic capacity of all cells, that is increased in association with the primary LH surge. Second, increased numbers of LHRH-expressing cclls are cvident at more rostral regions at a later time on proestrus than those in the medial preoptic area (mPOA). Third, and equally surprising, peak numbers of LHRH-expressing cells are evident in the mPOA prior to the initiation of the LH surge. Our results are consistent with a model proposed on the basis of immunocytochemical studies (Hiatt et al., 1992), whereby subgroups of LHRH cells are "recruited" into a more active biosynthetic state in anticipation of the preovulatory LHRH surge.

\section{Materials and Methods}

Animals. Forty-eight female rats (180-200 gm; Charles River Laboratories, Wilmington, MA) were maintained on a $14 \mathrm{hr}$ light/10 hr dark lighting schedule (lights on at 0500) and fed ad libitum. Estrous cycles were monitored by daily inspection of vaginal cytology. After at least three complete $4 \mathrm{~d}$ cycles were recorded, the animals were divided into groups of six, representing different phases of the periovulatory period. The groups were as follows: proestrus (Pro) $0800 \mathrm{hr}$, Pro $1200 \mathrm{hr}$, Pro $1800 \mathrm{hr}$, Pro $2200 \mathrm{hr}$, estrus (E) $0200 \mathrm{hr}$, E $0800 \mathrm{hr}$, E $1800 \mathrm{hr}$, and metestrus (Met) $1800 \mathrm{hr}$. The groups were chosen to coincide with times when LHRH release is known to be maximal during Pro $(1800 \mathrm{hr})$ and to reach a second peak during $E(0200 \mathrm{hr})$, before and after LHRH release is augmented during Pro and E $(0800 \mathrm{hr}$ Pro, $1200 \mathrm{hr}$ Pro, 0800 $\mathrm{hr}$ E), and, for comparison, during a morning or afternoon hour on other days of the cycle $(0800 \mathrm{Met}, 1800 \mathrm{hr}$ E) when LHRH release is likely maintained at a basal rate (Sarkar et al., 1976; Levine and Ramirez, 1982). The time points were also chosen to represent cycle stages in which the steroid milieu is distinctly different (Neguin et al., 1979): prior to preovulatory estrogen secretion (Met 0800), during preovulatory estrogen secretion (Pro 0800, 1200), during the proestrous progesterone surge (Pro 1800, 2200), and following the proestrous progesterone surge (E 0200, 0800, 1800). Animals were decapitated, and trunk blood was collected into vials containing $0.5 \mathrm{ml}$ of $0.3 \mathrm{M}$ EDTA and centrifuged. Plasma was stored at $-20^{\circ} \mathrm{C}$ until $\mathrm{LH}$ and FSH RIA. Brains were rapidly removed, frozen on dry icc, and stored at $70^{\circ} \mathrm{C}$ until scctioning.

In situ hybridization procedures. Coronal sections $(20 \mu \mathrm{m})$ were cut with a cryostat through the basal forebrain, from the caudal extremity of the suprachiasmatic nucleus (SCN) to the rostralmost portions of the diagonal band of Broca (DBB). Every other section from the SCN through the DBB was analyzed by LHRH in situ hybridization procedures. Sections were postfixed in $4 \%$ paraformaldehyde ( $\mathrm{pH} \mathrm{7.4)}$ for $5 \mathrm{~min}$ at $+4^{\circ} \mathrm{C}$, washed in cold phosphate buffer $\left(0.1 \mathrm{M} \mathrm{Na}_{2} \mathrm{HPO}_{4}, 0.15 \mathrm{M} \mathrm{NaCl}\right.$, $\mathrm{pH} \mathrm{7.4)} \mathrm{for} 2 \mathrm{~min}$, acetylated $10 \mathrm{~min}$ in $0.15 \%$ triethanolamine containing $2 \%$ acetic anhydride, dehydrated with $70 \%, 95 \%$, and $100 \%$ ethanol ( $2 \mathrm{~min}$ each), delipidated $5 \mathrm{~min}$ in chloroform, and rehydrated finally through $100 \%$ to $95 \%$ ethanol. An oligonucleotide probe (48 bases, complementary to the LHRH coding region, nine intervening nucleotides between LHRH and GAP, first nine bases of the GAP coding region of pro-LHRH) was labeled at the $3^{\prime}$ cnd with ${ }^{3}$ S-dATP (New England Nuclear-DuPont, Boston, MA) using terminal transferase (GIBCO-Bethesda Research Labs, Grand Island, NY). The labeling reaction proceeded for $1.5 \mathrm{hr}$ at $37^{\circ} \mathrm{C}$. The probe was purified using NENsorb 20 Nucleic Acid Purification Cartridges (New England Nuclear-DuPont, Boston, MA). The purified probe was mixed with $1 \%$ yeast tRNA solution (GIBCO-Bethesda Research Labs, Grand Island, NY) and TED (10 mM Tris, 1 mM EDTA, $10 \mathrm{~mm}$ dithiothreitol) buffer, heated to $+70^{\circ} \mathrm{C}$ for $3 \mathrm{~min}$, and cooled on ice. The final concentration of the probe in the hybridization mixture $(50 \%$ formamide, $10 \%$ dextran-sulfate, $0.3 \mathrm{M} \mathrm{NaCl}, 10 \mathrm{~mm}$ Tris, $1 \mathrm{~mm}$ EDTA, $1 \times$ Denhardt's, and $10 \mathrm{~mm}$ dithiothreitol) was $2.5 \mathrm{pmol} / \mathrm{ml}$, and the specific activity was $4100 \mathrm{Ci} / \mathrm{mmol}$. Sections were covered with $45 \mu$ l of hybridizing mixture, coverslipped, and incubated overnight at $37^{\circ} \mathrm{C}$. The slides were washcd in $1 \times \operatorname{SSC}(0.15 \mathrm{M} \mathrm{NaCl}, 0.015 \mathrm{M}$ sodium citratc, $\mathrm{pH} 7.0) 4 \times$ $15 \mathrm{~min}$ at $55^{\circ} \mathrm{C}$ followed by $2 \times 1 \mathrm{hr}$ washes at room temperature. After dehydration through a graded series of ethanols containing $6 \%$ ammonium acetate, the slides were dipped in photographic emulsion (Kodak NTB-2, Int. Biotech, Inc., New Haven, CT) diluted 1:1 with $0.6 \mathrm{M}$ ammonium acetate, and exposed 3 weeks at $4^{\circ} \mathrm{C}$. Slides were developed and stained lightly with $0.1 \%$ cresyl violet. The specificity of the hybridization signal was assessed by adding excess $(250 \mathrm{pmol} / \mathrm{ml})$ unla-

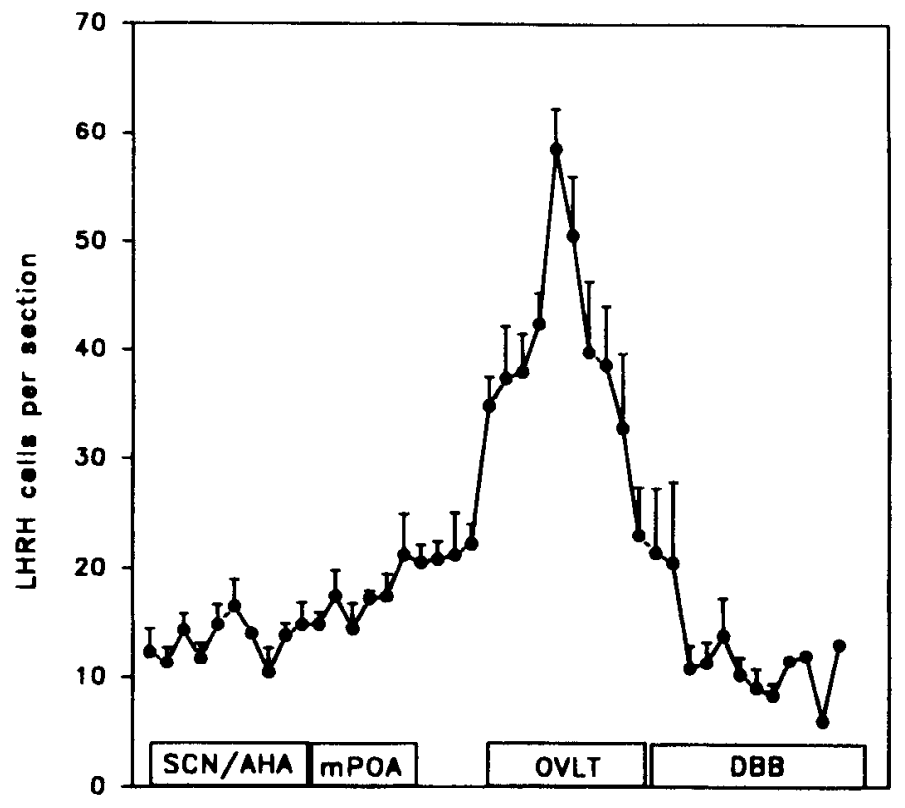

Figure 1. Average numbers of LHRH cells $/ 20 \mu \mathrm{m}$ tissue section at different rostrocaudal positions of the basal forebrain of the rat. The rostrocaudal delineations of these regions were used in the subsequent analysis of the data (suprachiasmatic nucleus/anterior hypothalamic area, $S C N / A H A$; medial preoptic area, $M P O A$; rostral preoptic area/ organum vasculosum of the lamina terminalis, $O V L T$; vertical limb of the diagonal band of Broca, $D B B$ ). The distribution profile was calculated from cell counts in proestrus animals killed at $1800 \mathrm{hr}(n=5$ rats). Points represent average LHRH cells/section \pm SE in every other section starting at $-1.3 \mathrm{~mm}$ and ending at $0.7 \mathrm{~mm}$ from bregma (Paxinos and Watson, 1986).

beled probe to the hybridization mixture, and treatment of sections with RNase $(10 \mu \mathrm{g} / \mathrm{ml})$. Both of these treatments abolished the signal.

All brain sections from all animals were processed in a single hybridization assay to allow for direct comparison of (non-normalized) LHRH gene expression among time points.

Analysis of hybridization results. Sections were atlas matched and slides were selected from four levels of the basal forebrain. Respectively, these levels included (1) the vertical limb of the DBB [coordinates according to Paxinos and Watson's Atlas of the rat brain (1986): +0.7 to $+0.2 \mathrm{~mm}$ from bregma], (2) rostral preoptic area/organum vasculosum of the lamina terminalis (rPOA/OVLT) (coordinates +0.2 to + $0.3 \mathrm{~mm}$ from bregma), (3) medial POA (mPOA coordinates -0.4 to $-0.8 \mathrm{~mm}$ from bregma), and (4) suprachiasmatic/anterior hypothalamic area (SCN/AHA) (coordinates -0.8 to $-1.3 \mathrm{~mm}$ from bregma) (Fig. 1). These levels were chosen on the basis of anatomical and physiological data (Jennes and Stumpf, 1986; Silverman et al., 1987; Hoffman et al., 1990; Hiatt et al., 1992), suggesting heterogeneity of function among LHRH neuronal populations at different rostrocaudal coordinates. They are closely matched to levels described in the immunocytochemical studies of Hiatt et al. (1992) and Hoffman et al. (1990), to facilitate subsequent comparison and interpretation of results.

Cells were identified using bright-field and dark-field microscopy to localize grain clusters over cell bodies stained with cresyl violet. Only cells that expressed at least three times background were included in calculations. The number of LHRH neurons was averaged for each animal among 6-12 (6 for mPOA, 12 for rPOA/OVLT, and 9-11 for SCN/AHA and DBB) sections/area and means were derived for each area at each time point. In a second analysis, the degree of LHRH gene expression per cell was estimated by obtaining average brightness/cell mcasurcments from atlas-matchcd scctions for each time point $(10$ cells/ section for mPOA and 35 cells for rPOA/OVLT). Intensity of labeling was measured in dark field using a computerized image analysis system (IMAGE-1, Universal Imaging Corporation, Media, PA), which calculates the brightness of specified areas obtained from dark-field images. The brightness scale was adjusted (1-256) by setting the gain and black level based on the relative background and intensity of the hybridization signal. These settings were consistent throughout the assay and enabled 


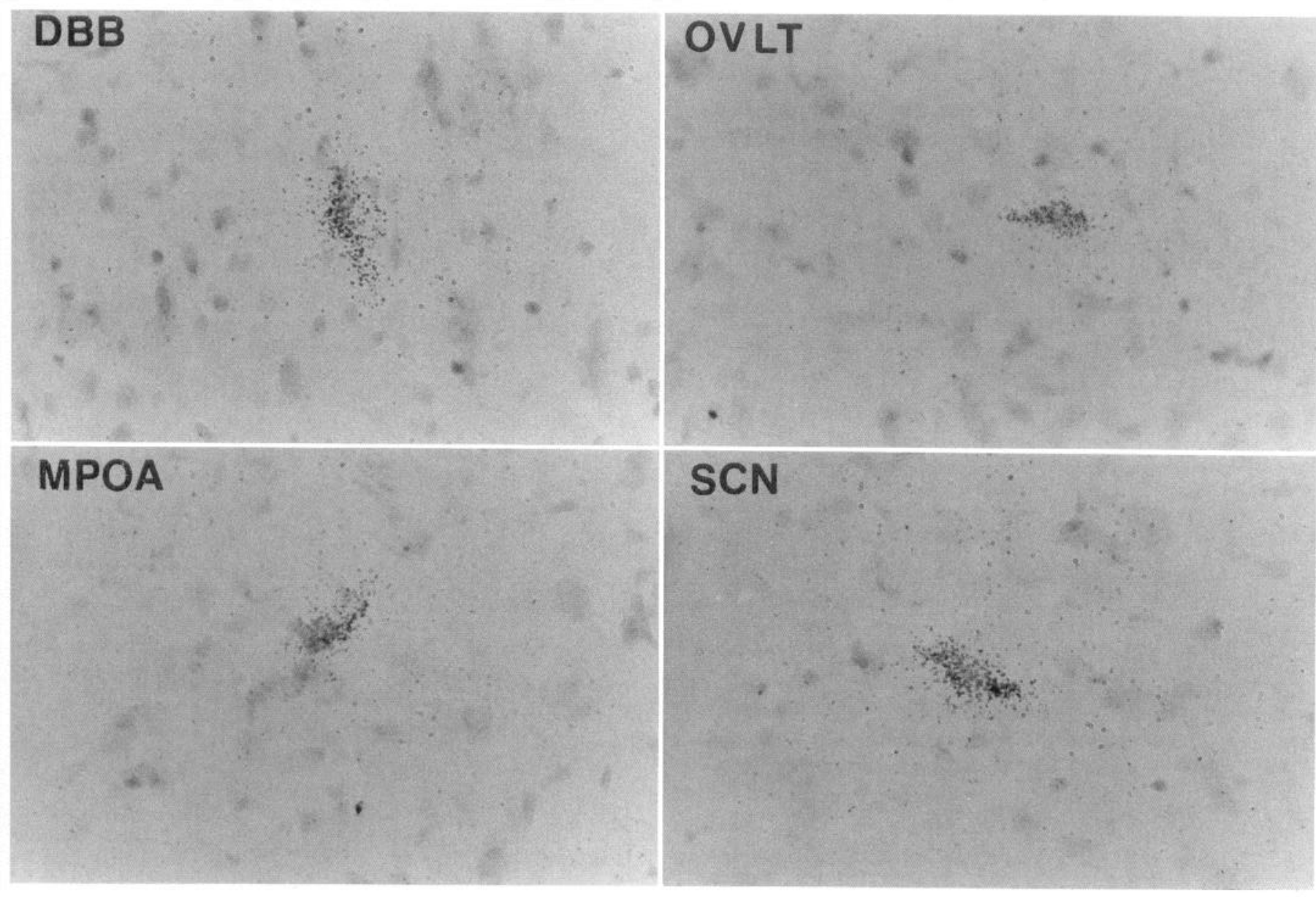

Figure 2. Bright-field photomicrographs of emulsion-coated sections showing neurons expressing LHRH mRNA in the four regions: diagonal band of Broca $(D B B)$, rostral preoptic area and organum vasculosum of the lamina terminalis $(O V L T)$, medial preoptic area $(m P O A)$, and suprachiasmatic nucleus and anterior hypothalamic area $(S C N)$. Anatomical characteristics were indistinguishable among LHRH-expressing neurons in the four regions.

us to analyze our data on a linear scale. Using this system, it has previously been demonstrated that area brightness is linearly related to the number of silver grains in that area (Kornhauser et al., 1990). The image analysis was carried out for only mPOA and rPOA/OVLT regions, since too few neurons were observed at some time points in the DBB and SCN/AHA for valid comparisons. The frequency distribution of area brightness values for cells in mPOA in groups M08, P12, and E08 was calculated for all cells expressing LHRH mRNA.

Radioimmunoassays. The LH and FSH contents of plasma samples were analyzed by RIA using materials supplied by NIDDK. For LH RIA, the NIDDK-anti-rLH-S-10 antiserum and the RP-3 standard was used in a single assay that exhibited a $9.0 \%$ intra-assay coefficient of variation and a minimum detectable limit of $0.3 \mathrm{ng} / \mathrm{ml}$. In the FSH RIA the NIDDK-anti-rFSH-S-11 FSH antiserum and the RP-2 standard were utilized, with a $12 \%$ intra-assay coefficient of variation and $2 \mathrm{ng} / \mathrm{ml}$ lower detection limit.

Statistical analysis. Groups were compared using one-way analysis of variance (GLM procedure in SAS, SAS Institute Inc., Cary, NC) followed by a post hoc Duncan's multiple range test. Differences between the groups were regarded as significant when $p<0.05$.

\section{Results}

Distribution and characteristics of LHRH $m R N A$-expressing neurons

The distribution and density of neurons expressing LHRH mRNA were found to correspond closely with findings from previous immunocytochemical (Hiatt et al., 1992) and in situ hybridization studies (Ronnekleiv et al., 1989; Malik et al., 1991). Figure 1 shows the average number of LHRH mRNA- expressing cells per $20 \mu$ tissue section (PRO 1800 hr group, $n$ $=5$ animals) at various rostrocaudal coordinates along the basal forebrain. The greatest numbers of labeled neurons are situated in the OVLT, followed in decreasing order by the mPOA, SCN/ $\mathrm{AHA}$, and DBB. In more rostral regions the distribution of LHRH neurons exhibited the characteristic inverted " $V$ " pattern. The mediobasal hypothalamus was found to contain only scant numbers of LHRH mRNA-expressing neurons. Estimates of the total number of cells in groups exhibiting lower numbers (e.g., PRO 2200 hr, E 0200 hr, E 0800 hr) were in close agreement with previous estimates ( 1200 cells; Malik et al., 1991). The degree of labeling/cell fell within similar ranges for neurons at all rostrocaudal coordinates (90-235 relative brightness units), and the gross morphology of labeled cells was also typically fusiform in all areas examined (Fig. 2).

\section{Cellular labeling intensities during the estrous cycle}

The average LHRH labeling intensity/cell was calculated from brightness measurements of grain clusters over cells in the rPOA OVLT and $\mathrm{mPOA}$ regions at each of the eight time points. Background value was obtained for every section separately by measuring the brightness value of an area that equalled the area of the cell in the immediate vicinity of the cell. Figure 3 depicts average brightness data from the $\mathrm{mPOA}$ and $\mathrm{rPOA} / \mathrm{OVLT}$ regions at each of the eight times of death. Statistical compar- 
isons revealed no differences between time points or among rostrocaudal regions.

\section{LHRH cell number during the estrous cycle}

The number of neurons expressing LHRH mRNA was found to vary significantly across the time points in mPOA (Figs. 4, $5 a$ ) and rPOA/OVLT (Figs. 5b, 6), but not in DBB (Fig. 7a) and SCN/AHA (Fig. 7b). Moreover, the temporal characteristics of these changes in LHRH cell number were found to differ between $\mathrm{MPOA}$ and $\mathrm{rPOA} / \mathrm{OVLT}$ region (Fig. 5). Changes in cell number did not appear to be due to overall changes in LHRH gene expression in entire LHRH neuronal populations; rather, the additional cells appeared to be subpopulations in which LHRH gene expression occurred in a virtually all-ornone fashion, depending upon the time of death. Demonstrating this effect, Figure 8 compares the frequency at which different intensities of labeling were observed in LHRH cells in mPOA sections at $1200 \mathrm{hr}$ proestrus versus $0800 \mathrm{hr}$ estrus and 0800 metestrus. The frequency distribution of labeling intensities was similar for all groups, with the exception being significantly more cells observed in the medium brightness level bins (151-190 intensity) in the $1200 \mathrm{hr}$ group. The numbers of cells exhibiting the lower (91-150) or higher (191-210) labeling intensities were not different between the groups.

$m P O A$. The number of LHRH neurons in $\mathrm{mPOA}$ sections fluctuated in a distinct cycle throughout the times examined, with highest numbers occurring at $1200 \mathrm{hr}$ proestrus (Fig. 5a). Figure 4 shows dark-field photographs of representative sections through the mPOA $(-0.5 \mathrm{~mm}$ from bregma). Average LHRH cell number declined after $1200 \mathrm{hr}$ proestrus in a stepwise fashion to a low point at $0800 \mathrm{hr}$ estrus, and then rose again in a similar manner through $1800 \mathrm{hr}$ estrus, $0800 \mathrm{hr}$ metestrus, and $0800 \mathrm{hr}$ proestrus. The peak cell number expressed at $1200 \mathrm{hr}$ proestrus was $80 \%$ greater than the nadir cell number at 0800 hr estrus. The number of LHRH-labeled cells was significantly greater in the $1200 \mathrm{hr}$ group versus estrus $0200 \mathrm{hr}$ and estrus $0800 \mathrm{hr}(p<0.05$; Fig. $5 a)$.

$r P O A / O V L T$. The number of I.HRH neurons in rPOA/OVLT sections also fluctuated throughout the cycle (Figs. $5 b, 6$ ), but these changes in cell number differed in at least two ways from those that occurred in the mPOA. The most obvious difference was that peak numbers of LHRH neurons were noted at 1800 $\mathrm{hr}$ in the rPOA/OVLT, whereas the greatest numbers of LHRH neurons in the mPOA were evident $6 \mathrm{hr}$ earlier, at $1200 \mathrm{hr}$ proestrus. A second difference was the relatively abrupt manner in which the number of LHRH cells in the rPOA/OVLT was reduced at $2200 \mathrm{hr}$ : following the attainment of peak numbers at $1800 \mathrm{hr}$, cell number fell from maximum to minimum value during the cycle (reduction of $40 \%$ ) within just a $4 \mathrm{hr}$ period.

$D B B$ and $S C N / A H A$. The number of neurons expressing LHRH mRNA in the DBB (Fig. 7a) and SCN/AHA regions (Fig. $7 b$ ) did not change significantly throughout the estrous cycle times examined.

\section{Periovulatory hormone secretions}

Average plasma LH and FSH levels as determined by RIA were typical for all of the estrous cycle time points that were examined (Fig. 9a,b). The LH levels remained low $(0.22-0.36 \mathrm{ng} / \mathrm{ml})$ at $0800 \mathrm{hr}$ metestrus, $0800 \mathrm{hr}$ proestrus, and $1200 \mathrm{hr}$ proestrus, and reached values typical for the apex of the LH surge (11.0 $\mathrm{ng} / \mathrm{ml}$ ) at $1800 \mathrm{hr}$. The LH levels were more than halved by $2200 \mathrm{hr}$ proestrus, and completely returned to baseline values
A.

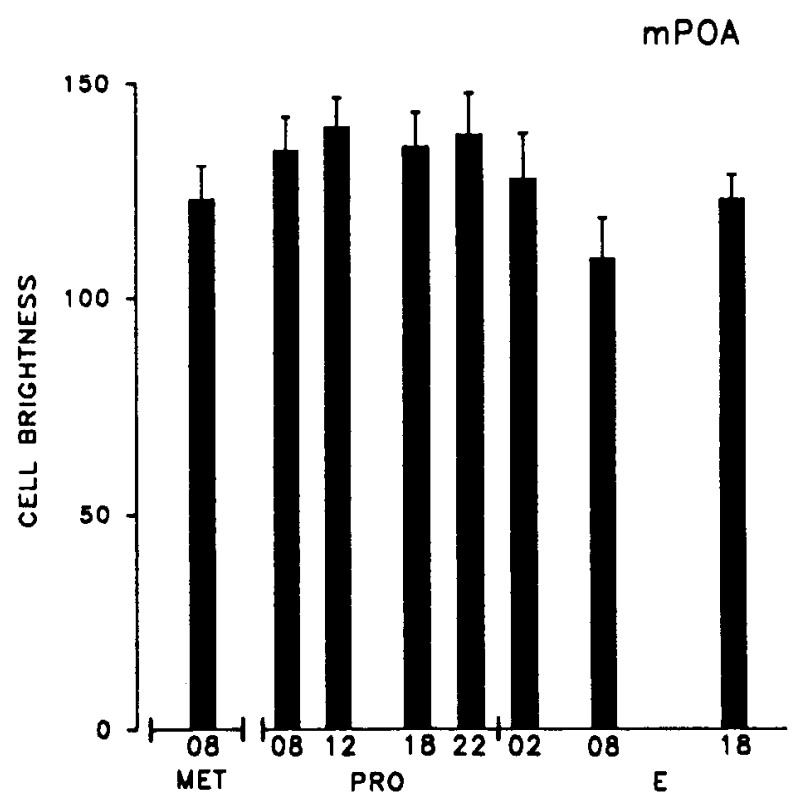

B.

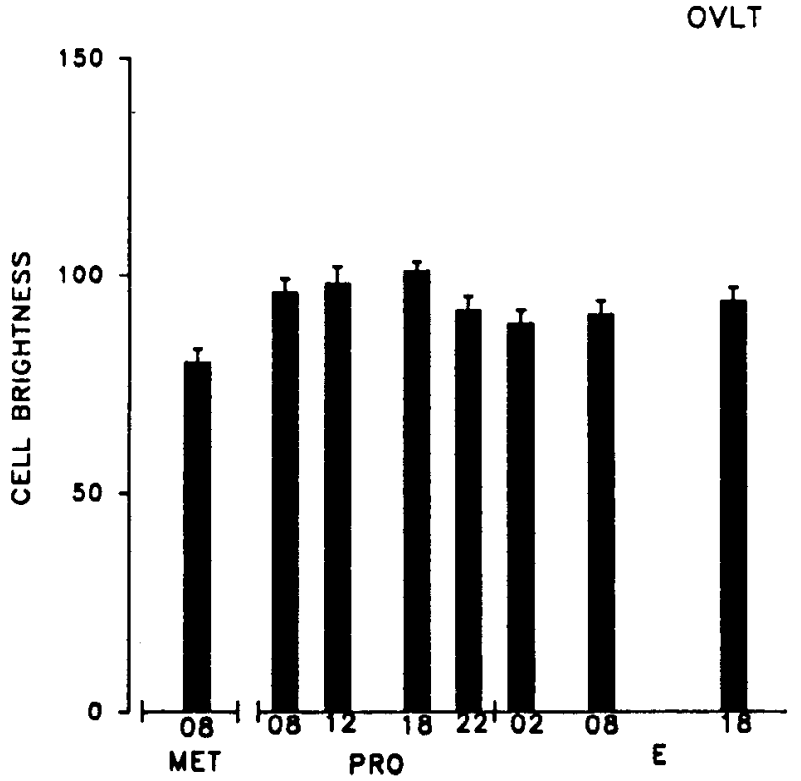

Figure 3. Area brightness of cells expressing LHRH mRNA in the medial preoptic area $(m P O A)$ and at the level of the rostral preoptic area/organum vasculosum of the lamina terminalis ( $O V L T)$ during different stages of the estrous cycle. Groups of rats $(n=5-6)$ were killed at metestrus (MET) $0800 \mathrm{hr}(08)$, proestrus $(P R O) 0800 \mathrm{hr}(08), 1200$ $\mathrm{hr}(12), 1800 \mathrm{hr}(18)$, and $2200 \mathrm{hr}(22)$, and estrus $(E) 0200 \mathrm{hr}(02)$, $0800 \mathrm{hr}(08)$, and $1800 \mathrm{hr}(18)$, and brain sections from mPOA region were hybridized with a ${ }^{35} \mathrm{~S}$-labeled oligonucleotide probe (see Materials and Methods for details of hybridization analysis). Atlas-matched sections were subjected to computerized image analysis that expresses labeling intensity as area brightness values. Ten cells per section for each rat were analyzed, the mean for each rat was calculated, and the average value for each group was obtained. No significant differences in labeling intensities were found for cither area between the time points. 

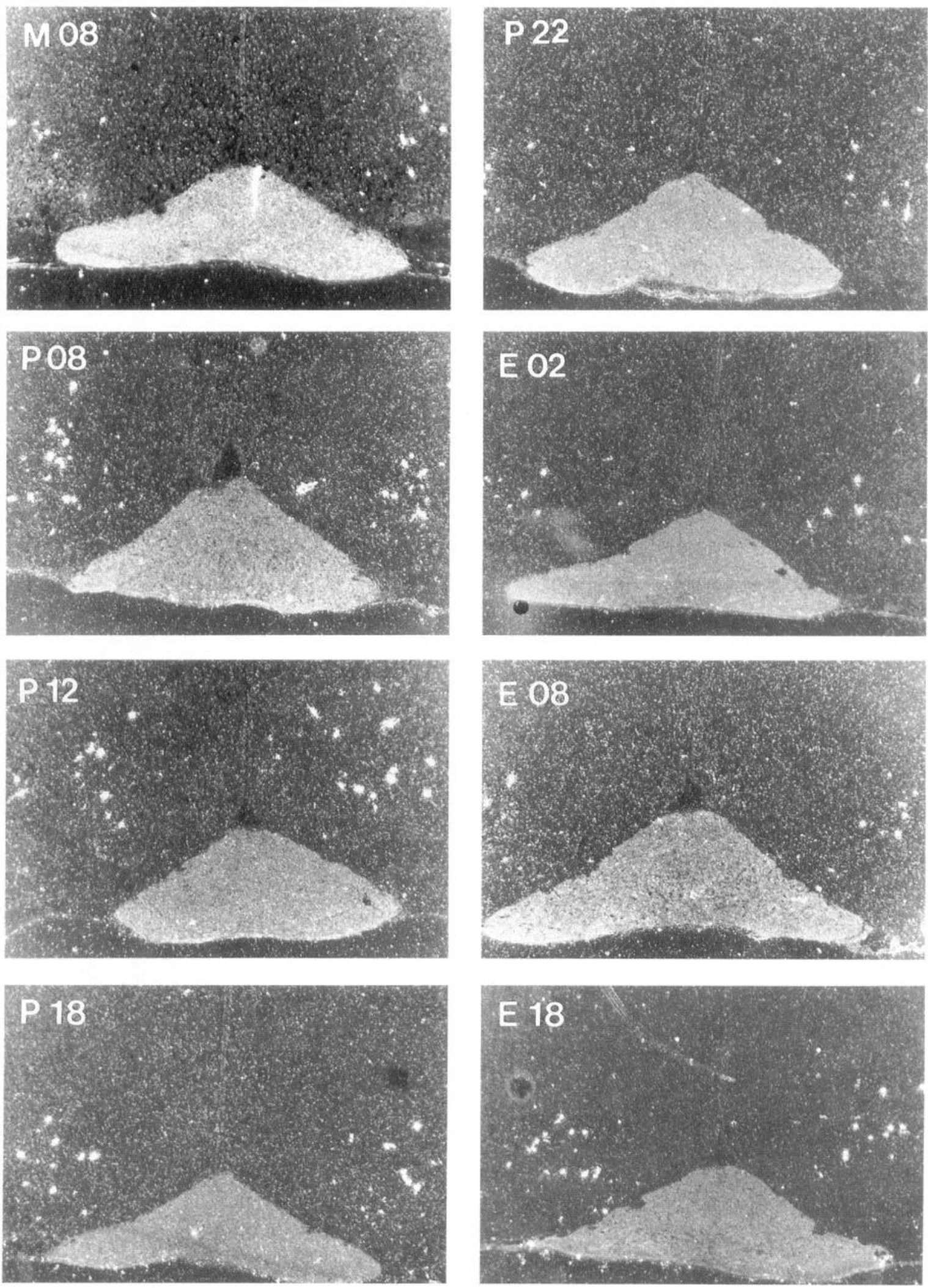

Figure 4. Composite, dark-field photomicrographs showing labeling of LHRH mRNA-containing cells in representative atlas-matched sections in the medial preoptic area (mPOA) at different times during the estrous cycle. LHRH cells expressing LHRH mRNA are visualized by in situ hybridization. Groups and time points are the same as described in the legend to Figure 3. Number of cells expressing LHRH mRNA is high in the morning of proestrus (at P08 and P12), declining gradually in the afternoon of proestrus and estrous day. See also summary of results in Figure $5 a$. 
by $0200 \mathrm{hr}$ estrus. Average FSH levels were $4.8 \mathrm{ng} / \mathrm{ml}$ at 0800 hr metestrus, and these declined to $2.1 \mathrm{ng} / \mathrm{ml}$ at $1200 \mathrm{hr}$ proestrus, presumably under increasing negative feedback suppression by ovarian estrogen (Daanc and Parlow, 1971; Neguin et al., 1979). As shown previously (Daane and Parlow, 1971; Savoy-Moore et al., 1980), the ascent of the primary FSH surge was in evidence at $1800 \mathrm{hr}$ proestrus $(8.7 \mathrm{ng} / \mathrm{ml})$ and peak levels were attained by $2200 \mathrm{hr}$ proestrus $(11.8 \mathrm{ng} / \mathrm{ml})$. A typical secondary release of FSH, occurring in the absence of sustained LH secretion (Daane and Parlow, 1971; Neguin et al., 1979; Savoy-Moore et al., 1980), was also confirmed in samples at $0200 \mathrm{hr}$ and $0800 \mathrm{hr}$ estrus.

\section{Relationships between regional LHRH cell number and hormone levels}

As depicted in Figures 4 and $5 a$, the peak number of LHRH neurons in the mPOA occurred at $1200 \mathrm{hr}$ proestrus before the onset of LH and FSH surges. A stepwise decline in the number of mPOA LHRH mRNA-expressing neurons occurred during the next two sampling points, $1800 \mathrm{hr}$ and $2200 \mathrm{hr}$ proestrus; this decrease coincided with the timing of the LH surge.

The rPOA/OVLT was found to contain the greatest number of LHRH neurons later in the afternoon (1800 hr proestrus) compared to the MPOA region (Figs. $5 b, 6$ ), and this peak in LHRH cell number coincided with the apex of the LH surge, rather than preceding it. However, like the mPOA, the rPOA/ OVLT region also exhibited a decrease in LHRH cell number as the LH surge was completed. In none of the four brain regions examined were there any alterations in the number of LHRH cells that were temporally.associated with the secondary release of FSH. During the time at which a secondary release of LHRH has been reported $(0200 \mathrm{hr})$ (Sarkar et al., 1976), there were no obvious changes in either parameter of LHRH gene expression, except for the continued decline in LHRH cell number that started at $1200 \mathrm{hr}$ proestrus and reached a nadir at $0800 \mathrm{hr}$ estrus.

\section{Discussion}

It is well established that the proestrous surge of LHRH (Sarkar et al., 1976; Levine and Ramirez, 1982) provides a neural trigger for the release of the preovulatory gonadotropin surge that, in turn, induces ovulation (Schwartz, 1974). The positive feedback actions of ovarian estrogen (Legan et al., 1975), together with a signal from the $24 \mathrm{hr}$ neural clock (Legan and Karsch, 1975), operate as primary cues for the release of the LHRH surge. Additionally, ovarian (Krey et al., 1973) and/or adrenal (Feder et al., 1971) progesterone released prior to the gonadotropin surge (Kalra and Kalra, 1974) or as the surge proceeds (Aiyer and Fink, 1974) serve to amplify the LHRH/LH surge (Krey et al., 1973; Aiyer and Fink, 1974; Ramirez et al., 1980; Turgeon and Waring, 1981; Kim and Ramirez, 1982, 1985) and block its continued occurrence on subsequent afternoons (Freeman et al., 1976). While it is certain that LHRH neurons are acutely activated under these preovulatory hormonal conditions, the inter- and intracellular mechanisms by which gonadal and circadian cues are transduced and conveyed to the LHRH release apparatus remain unclear.

Previous work supports the contention that LHRH biosynthetic activity is changed in some manner before the onset of the LHRH surge. Immunoreactive LHRH is increased to a maximum at $1200 \mathrm{hr}$ on proestrus in the MPOA and other hypothalamic and extrahypothalamic areas (Wise et al., 1981; Parnet
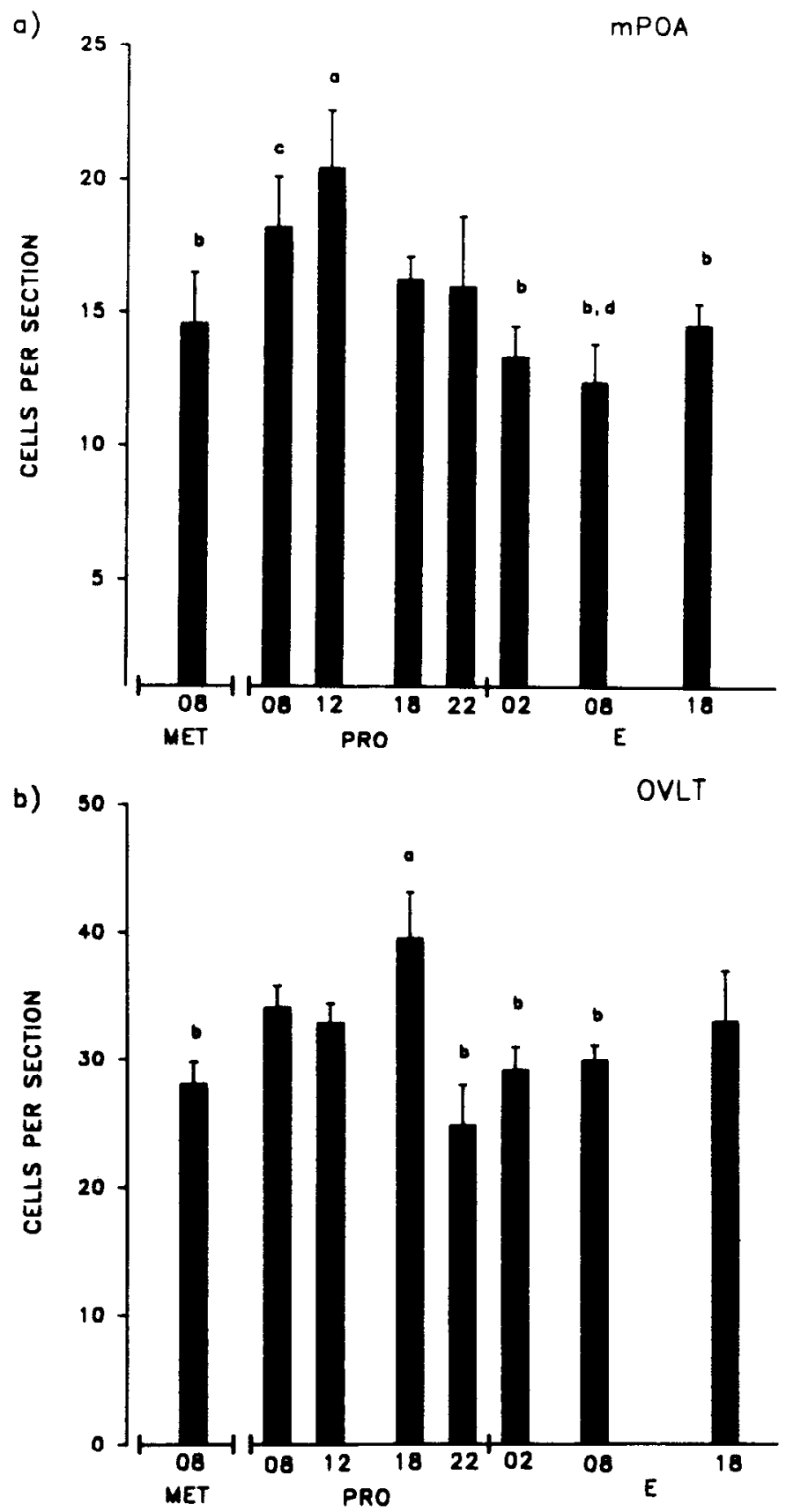

Figure 5. Average number of cells/section expressing LHRH mRNA at the level of the medial preoptic area $(M P O A, a)$ and the rostral preoptic area/organum vasculosum of the lamina terminalis $(O V L T, b)$ at different times of the estrous cycle. Groups and time points are as described in the legend to Figure 3. Significant differences $(p<0.05)$ among average values in different groups are noted as $a$ versus $b$, and as $c$ versus $d$. In the mPOA region LHRH mRNA expression was highest at PRO $1200 \mathrm{hr}$, well before the start of LHRH/LH surge. In the rPOA/ OVLT region, the maximal number of LHRH neurons expressing mRNA was found at PRO $1800 \mathrm{hr}, 6 \mathrm{hr}$ later than in $\mathrm{mPOA}$. The gene expression in mPOA declines gradually to a minimum value at the morning of estrous day. In the rPOA/OVLT, gene expression declines abruptly at PRO $2200 \mathrm{hr}$, reaching the minimum value of the cycle at this time point.

et al., 1990). Likewise, immunocytochemical studies have shown that subpopulations of LHRH neurons are detectable at 1100 $1300 \mathrm{hr}$ proestrus, but not on other days of the cycle (Hiatt et al., 1992). In these RIA and immunocytochemical studies, 

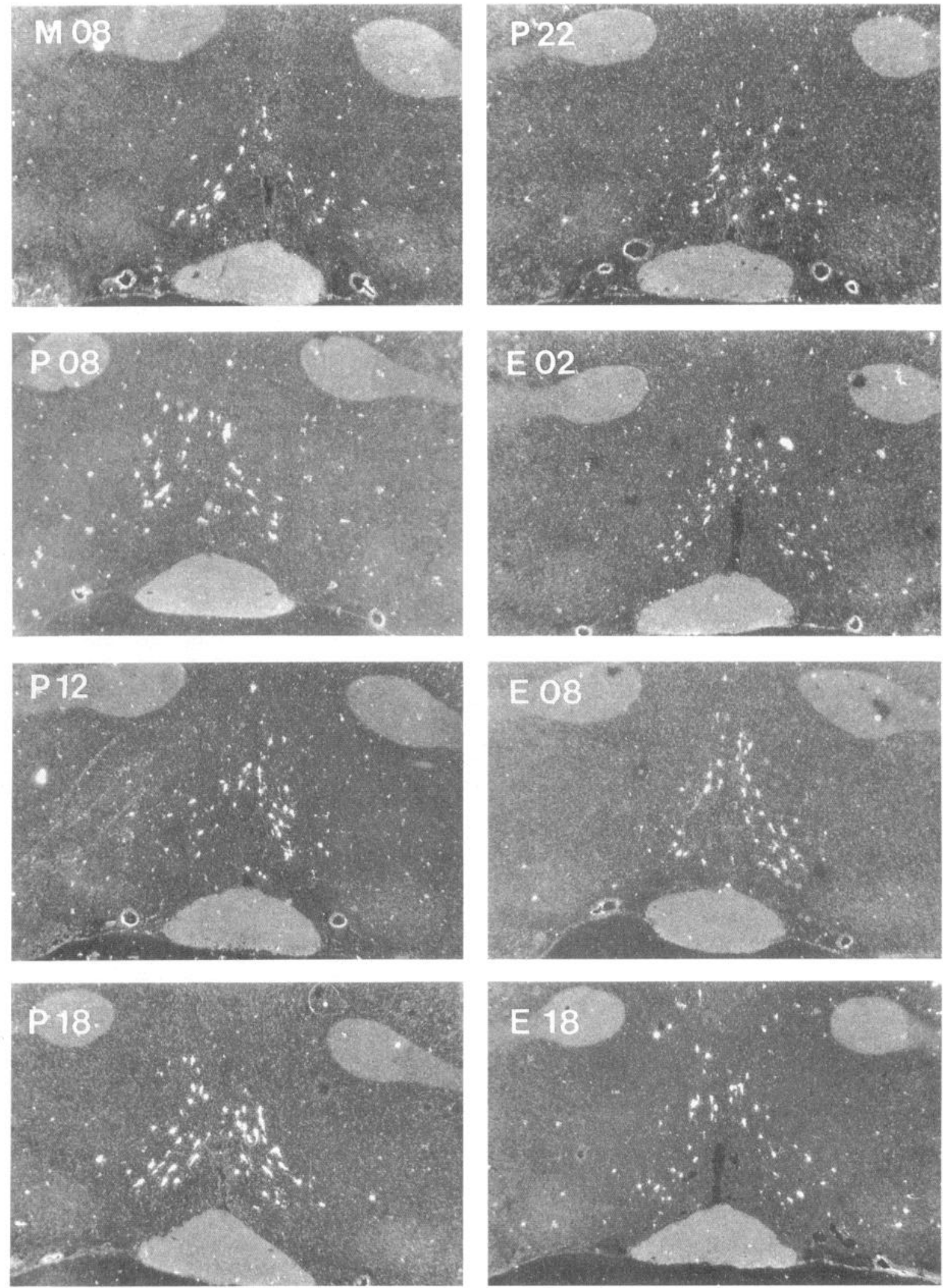

Figure 6. Composite of dark-field photomicrographs showing LHRH mRNA-expressing cells in rostral preoptic area/organum vasculosum of the lamina terminalis (rPOA/OVLT) of rats during different times of the estrous cycle. LHRH cells expressing LHRH mRNA are visualized by in situ hybridization. Groups and time points are the same as described in the legend to Figure 3. The number of LHRH mRNA-expressing cells increases gradually during proestrous morning (P08 and P12), reaching a maximum at $1800 \mathrm{hr}(P 18)$. Cell number declines abruptly at proestrous night $2200 \mathrm{hr}$. See also summary of results in Figure $5 b$. 
o)

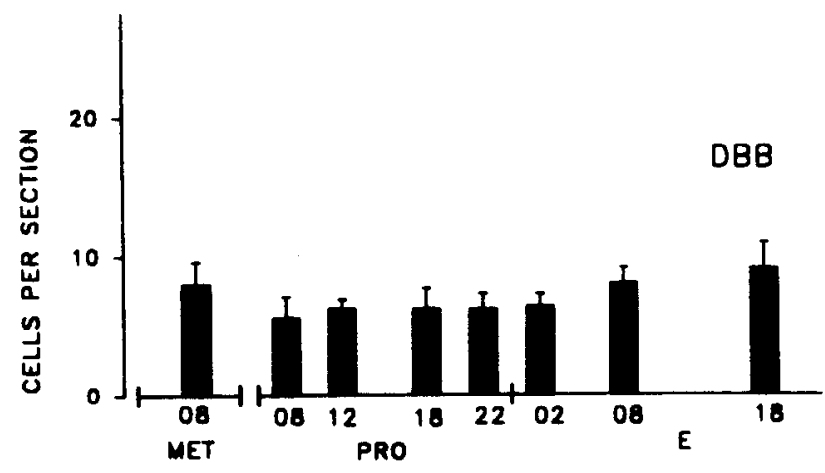

b)

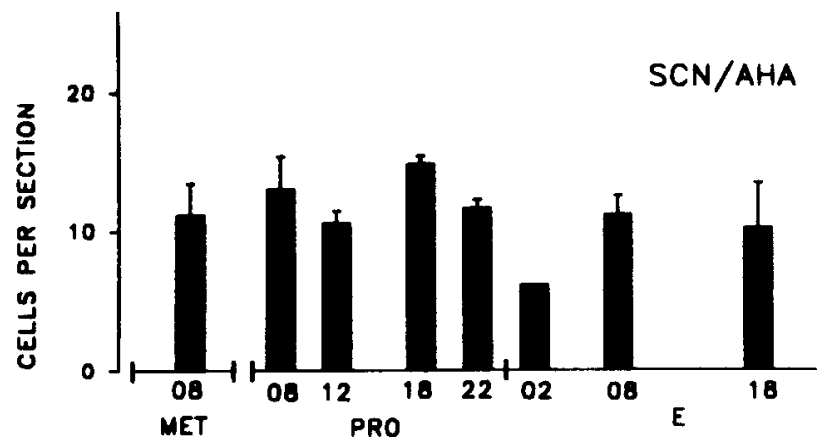

Figure 7. Number of cells expressing LHRH mRNA at different times of the rat estrous cycle in $(a)$ diagonal band of Broca $(D B B)$ and $(b)$ suprachiasmatic nucleus/anterior hypothalamic area $(S C N / A H A)$ regions. Groups and time points are as described in the legend to Figure 3. There was no difference between the groups at either area at any time point in the course of estrous cycle.

changes in LHRH immunoreactivity preceded the onset of the LH surge. Although the preovulatory LHRH surge is preceded by a period of little spontaneous (Sarkar et al., 1976; Levine and Ramirez, 1982) or inducible (Luderer et al., 1993) LHRH release, there are clearly alterations in biosynthetic activity during this same time period. Our findings are in direct agreement with these immunocytochemical studies, suggesting these changes take place only within subpopulations of LHRH cells, and that they essentially occur as episodes of synthetic activity that precede and coincide with LHRH and LH surges. The function of this presurge induction of LHRH gene expression may be to supply neurosecretory terminals with an enlarged releasable LHRH pool at the time of the LHRH surge. It is also possible, however, that LHRH production may be augmented to replenish stores of the decapeptide following the preovulatory LHRH and $\mathrm{LH}$ surges.

Comparison of the present findings with previous in situ hybridization results is hampered by the fact that in no other study were all features of LHRH gene expression examined, namely, LHRH cell number, LHRH gene expression/cell, regional changes in LHRH gene expression, and temporal patterns of periovulatory LHRH gene expression. Park et al. (1990) analyzed LHRH cell number among all LHRH neurons in the basal forebrain as a single group, and found that overall numbers increased to a maximum at $1800 \mathrm{hr}$ proestrus. Our results are similar to these, inasmuch as the total number of neurons fluctuated in the same manner in the present study; since a disproportionale number of LHRH neurons are present in the rPOA/ OVLT region, the overall mean number of neurons for all areas in this study was also highest at $1800 \mathrm{hr}$. When examined within discrete regions, however, the number of LHRH neurons within

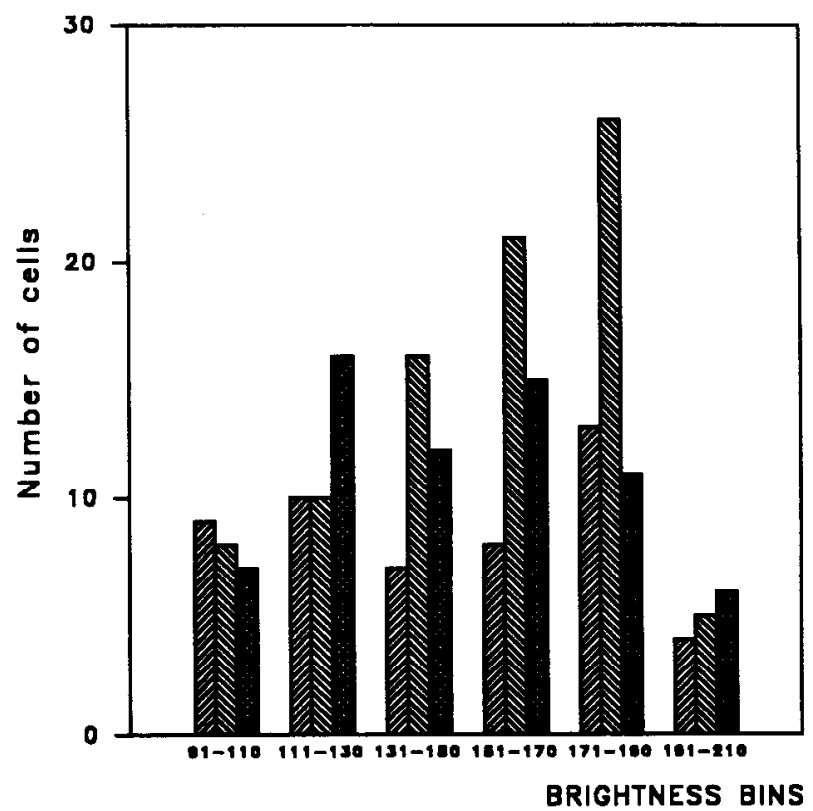

Figure 8. Frequency distribution of area brightness values of all cells expressing LHRH mRNA in the medial preoptic area (mPOA) measured in the following groups: metestrus at $0800 \mathrm{hr}(\mathbb{Z})$, proestrus 1200 $\mathrm{hr}(\mathbb{\mathbb { Q }})$, and estrus $0800 \mathrm{hr}$ (圈). All cells expressing LHRH mRNA in $\mathrm{mPOA}$ at M $0800 \mathrm{hr}$, PRO $1800 \mathrm{hr}$, or E $0800 \mathrm{hr}$ were subjected to image analysis and the obtained area brightness values were divided to brightness groups. The frequency of cells in each group at the three time points is illustrated in the figure. The additional cells expressing LHRH mRNA at PRO $1200 \mathrm{hr}$ appear in the medium brightness groups: no shifting of cells from low brightness groups to high brightness groups at this time point is found.

the mPOA clearly peaked at $1200 \mathrm{hr}$, a time that preceded the peak number in more rostral regions, and preceded the onset of the LH surge. While the study of Park et al. (1990) examined ccll number and not LHRH expression/ccll during the estrous cycle, the previous study of Zoeller and Young (1988) focused only on expression of LHRH/cell and not LHRH cell number. Moreover, the latter study evaluated changes at a single rostral region, the OVLT. Within the OVLT, a decrease in LHRH gene expression/cell was noted by Zoeller and Young (1988) between $1900 \mathrm{hr}$ metestrus and $1300 \mathrm{hr}$ proestrus, with a recovery to metestrus levels by $1900 \mathrm{hr}$ proestrus. The reason for our failure to observe the same changes in LHRH gene expression/cell in the OVLT during the same time period is not immediately apparent, although it should be noted that a third study (Malik et al., 1991) also failed to detect a similar change during the same time period. It is possible that technical differences between the two studies may be responsible for this disparity. In the present study, for example, we included all tissues within a single assay, and therefore could compare absolute hybridization intensities among groups. In the report of Zoeller and Young (1988), by contrast, gene expression/cell was analyzed and compared among groups after normalization with respect to metestrus values within each assay. In two other studies of LHRH gene expression during the estrous cycle (Malik, 1991; Marks et al., 1993), analysis of both LHRH cell number and LHRH gene expression/cell was carried out at several rostrocaudal regions. These two analyses, however, were limited to only three (Malik, 1991) or four (Marks et al., 1993) time points during the cycle and therefore are difficult to compare with our own analysis. The findings of Malik et al. (1991) are nevertheless in 

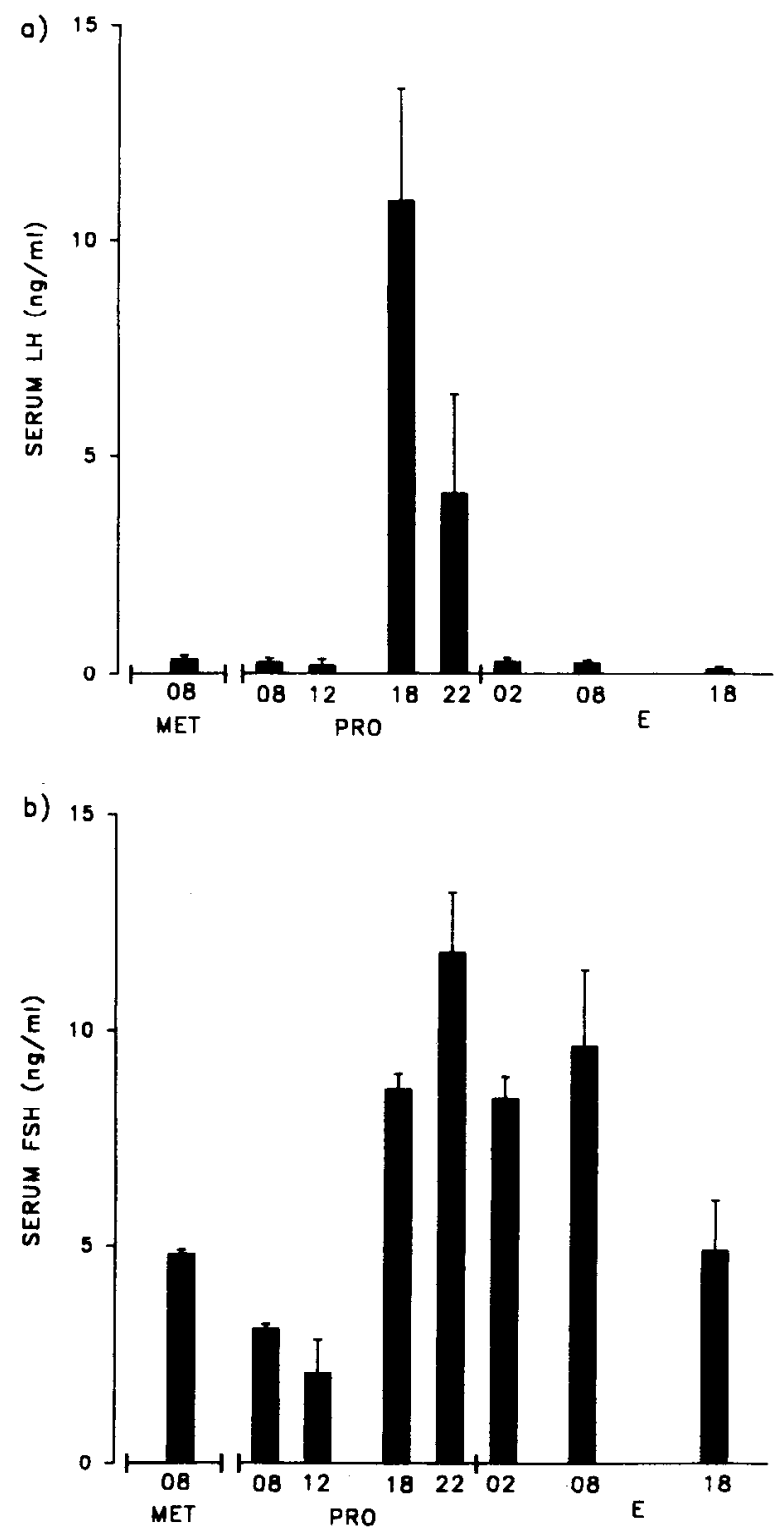

Figure 9. Serum hormone concentrations at different time points of the rat estrous cycle. Groups and time points are as described in the legend to Figure 3. $a$, serum LH; $b$, serum FSH. Average plasma LH and FSH levels were typical for all of the estrous cycle time points that were examined. The $\mathrm{LH}$ levels remained low at $0800 \mathrm{hr}$ metestrus, 0800 $\mathrm{hr}$ proestrus, and $1200 \mathrm{hr}$ proestrus, and reached values typical for the apex of the LH surge $(11.0 \mathrm{ng} / \mathrm{ml})$ at $1800 \mathrm{hr}$. The LH levels were more than halved by $2200 \mathrm{hr}$ proestrus, and completely returned to baseline values by $0200 \mathrm{hr}$ estrus. Average FSH levels were $4.8 \mathrm{ng} / \mathrm{ml}$ at 0800 $\mathrm{hr}$ metestrus and these declined to $2.1 \mathrm{ng} / \mathrm{ml}$ at $1200 \mathrm{hr}$ proestrus. The ascent of the primary FSH surge was in evidence at $1800 \mathrm{hr}$ proestrus $(8.7 \mathrm{ng} / \mathrm{ml})$ and peak levels were attained by $2200 \mathrm{hr}$ proestrus $(11.8$ $\mathrm{ng} / \mathrm{ml}$ ). A typical secondary release of FSH, occurring in the absence of sustained LH secretion, was also confirmed in samples at $0200 \mathrm{hr}$ and $0800 \mathrm{hr}$ estrus.

agreement with our experiments in three respects. First, they too did not observe any change in LHRH gene expression/cell from metestrus to the morning of estrus. Second, their analysis of LHRH cell number revealed that no significant increases occurred in the number of cells expressing LHRH mRNA among the proestrus $0700,1000 \mathrm{hr}$ estrus, and $1900 \mathrm{hr}$ metestrus time points. Third, there exists a close similarity between the absolute and relative cell number values of Malik et al. (1991) and our own values among these same time points.

In both regions that exhibited presurge LHRH gene induction (mPOA, rPOA/OVLT), the nadir number of LHRH neurons was $60-75 \%$ of the maximum number of LHRH neurons. This suggests that the subpopulation of LHRH cells whose function is related to ovulatory cyclicity represents approximately $35 \%$ of LHRH neurons in the basal forebrain. This percentage is in remarkably close agreement with the percentage of LHRH cells $(40 \%)$ that have been shown to express c-fos and thus are likely engaged in heightened activity during the preovulatory LH surge (Lee et al., 1990). Conversely, our data indicate that there also exists a large, core group of LHRH cells whose LHRH gene expression does not change in a manner related to LHRH and LH surges. Of the latter neurons, it is possible that some perform synaptic rather than neurosecretory functions (Jennes and Stumpf, 1986; Merchenthaler et al., 1989). The remaining population of LHRH cells may be composed of neurons that possess LHRH pulse-generating activity but do not exhibit increased ncurosecretory activity during the generation of LH surges.

Our data demonstrate for the first time that LHRH gene expression in a subpopulation of LHRH neurons is altered prior to the initiation of the LHRH surge. This suggests that the induction of LHRH gene expression in this subpopulation of mPOA neurons occurs in preparation for the enhanced neurosecretion of the decapeptide, rather than as a consequence of the surge release itself. Linkage of LHRH biosynthesis to neurosecretion has been suggested on the basis of the timing of mRNA increases relative to the LH surge in other studies (Zoeller et al., 1988; Park et al., 1990). In these cases, overall cell number (Park et al., 1990) or gene expression (Zoeller et al., 1988 ) in the OVLT was found to be increased during (Park et al., 1990) or following (Zoeller et al., 1988) the generation of the LH surge. Although overall LHRH cell number in the present study was also found to peak at $1800 \mathrm{hr}$, separate analysis of the mPOA alone revealed that cell number peaks in this neural region at a distinctly earlier time point $(1200 \mathrm{hr})$. It would therefore appear to be unlikely that LHRH hypersecretion could provide the stimulus for induction of LHRH gene expression in the mPOA subpopulation of cells, since LHRH surges do not occur until several hours later in the afternoon (Sarkar et al., 1976).

That induction of LHRH gene expression does not depend upon LHRH secretion is also supported by the observation that no secondary increases in LHRH cell number or apparent changes in mRNA levels/cell occurred at $0200 \mathrm{hr}$ estrus. This time point was chosen for examination on the basis of previous findings that LHRH secretion undergoes a secondary periovulatory increase which peaks at this time (Sarkar et al., 1976). This secondary release of LHRH has, in turn, been suggested to play a role in the secondary release of FSH during late proestrus and early estrus. Others have argued that alterations in gonadal peptide and/or steroid feedback (Ackland et al., 1990; Knox and Schwartz, 1992) and/or the release of a hypothalamic FSH-RF (Mizunoma et al., 1983) may figure more importantly in this regard. Regardless of the potential importance of LHRH secretion during estrus in the secondary surge of FSH, our data at least suggest that any secondary peak of LHRH neurosecretion at $0200 \mathrm{hr}$ is not associated with any alteration in cellular or population changes in LHRH gene expression, other than the continued decline in LHRH cell numbers from peak values in proestrus. By extension, then, alterations in LHRH gene ex- 
pression do not appear to be directly related to the continued surge release of FSH throughout the morning of estrus.

It is likely that circulating gonadal steroids provide important endocrine cues for the induction and reduction of LHRH gene expression in these subpopulations of neurons. It has long been known that estrogen treatments can evoke daily LH surges (Legan and Karsch, 1975; Legan et al., 1975) and that progesterone can amplify the afternoon surge (Krey et al., 1973; Ramirez et al., 1980) and inhibit the occurrence of the surge on subsequent days (Freeman et al., 1976). In normal cycling female rats, estrogen secretion by ripening follicles provides the positive feedback signal for stimulation of the preovulatory LHRH and LH surges (Kalra and Kalra 1983; Levine et al., 1991), and the proestrous progesterone surge both amplifies the estrogen-induced preovulatory I.H surge (Caligaris et al., 1971; Krey et al., 1973; Ramirez et al., 1980) and limits its occurrence to the afternoon of proestrus (Freeman et al., 1976). Estrogen treatment of ovariectomized rats has been shown to increase hypothalamic LHRH (Kobayashi et al., 1978) and pro-LHRH tissue content (Kelly et al., 1989; Roberts et al., 1989), and in most studies (Kim et al., 1989; Roberts et al., 1989; Rothfeld et al., 1989; Park et al., 1990; Rosie et al., 1990) stimulatory effects of estrogen on LHRH mRNA levels have been documented. Notably, Park et al. (1990) found an increase in the number of neurons expressing LHRH mRNA following estrogen treatment. It is therefore possible that LHRH gene expression in subpopulations of LHRH neurons is dependent upon exposure of these cells to preovulatory surge levels of circulating estrogen.

Proestrous progesterone secretion (Neguin et al., 1979) appears to be temporally associated with the decline in LHRH mRNA-producing cell number in the mPOA and rPOA/OVLT. It is well known that progesterone treatment of estrogen-primed animals can exert both positive and negative effects on LHRH release, inasmuch as it can augment and advance LHRH hypersecretion on proestrus (Ramirez et al., 1980; Kim and Ramirez, 1982, 1985) while also blocking the occurrence of LHRH/ LH surges on the following day (Freeman et al., 1976). The relationship between these effects on LHRH release and potential effects on LHRH gene expression, however, have not been entirely clear. In the study of Park et al. (1990), which demonstrated increased LHRH cell number following estrogen treatment, additional treatment with progesterone was found to reverse this effect. Inhibitory effects of progesterone on LHRH gene expression have also been noted in other studies (Toranzo et al., 1989). In one study where stimulatory effects were found (Kim et al., 1989), these were noted at a morning time point in immature animals; it is therefore difficult to compare these stimulatory effects with those that may occur in the late afternoon in adult female rats. We suggest that the progesterone surge on the afternoon of proestrus may take at least two different cellular routes to accomplish its two important tasks on proestrus. Progesterone clearly achieves the first of these tasks, namely, amplification of the preovulatory LHRH and LH surges, through its capacity to directly or indirectly stimulate LHRH release (Levine and Ramirez, 1980; Ramirez et al., 1980). Early stimulatory effects of progesterone on LHRH gene expression may also figure importantly in this process (Kim et al., 1989). Progesterone's second function, however, is to limit the expression of the LHRH/LH surge to the afternoon of proestrus, and the cellular and molccular basis of this action is not well understood. We suggest that the second action of progesterone may be me- diated by its effects on LHRH gene expression in subpopulations of LHRH cells. We hypothesize that progesterone may act to deactivate LHRH gene expression in the same subpopulations of cells in which LHRH gene expression was induced by estrogen, and thereby preclude their involvement in the generation of LHRH surges on the next day or, for that matter, until the next induction of gene expression by preovulatory estrogen secretion. Thus, the two steroids may conceivably act upon a molecular switch in opposing fashions, with preovulatory estrogen levels essentially switching "on" LHRH gene expression in these subpopulations of cells, and the progesterone surge returning this switch to the "off" position.

We conclude that subpopulations of neurons in the mPOA and rPOA/OVLT exist in which the cyclical expression of LHRH mRNA is temporally associated with the cyclical generation of preovulatory LHRH/LH surges. That this expression is not a consequence of LHRH neurosecretion at this time is indicated by its occurrence in the MPOA prior to the initiation of the preovulatory LH surge. The mechanism(s) by which ovarian steroids may instead be responsible for inducing and/or reducing LHRH gene expression at this time remains to be characterized.

\section{References}

Ackland JF, D'Agostino JD, Ringstrom SJ, Hostetler JP, Mann BG, Schwartz NB (1990) Circulating radioimmunoassayable inhibin during periods of transient follicle-stimulating hormone rise: secondary surge and unilateral ovariectomy. Biol Reprod 43:347-352.

Aiyer MS, Fink G (1974) The role of sex steroid hormones in modulating the responsiveness of the anterior pituitary gland to luteinizing hormone releasing factor in the female rat. J Endocrinol 62:553-572.

Caligaris J, Astrada J, Taleisnik S (1971) Biphasic effect of progesterone on the release of gonadotropin in rats. Endocrinology 89:331337.

Daane TA, Parlow AF (1971) Periovulatory patterns of rat serum follicle stimulating hormone and luteinizing hormone during the normal estrous cycle: effects of pentobarbital. Endocrinology 88:653-663.

Feder HH, Brown-Grant K, Corker CS (1971) Pre-ovulatory progesterone, the adrenal cortex and the critical period for luteinizing hormone release in rats. $\mathrm{J}$ Endocrinol 50:29-39.

Freeman MC, Dupke KC, Croteau CM (1976) Extinction of the estrogen-induced daily signal for LH release in the rat: a role for the proestrous surge of progesterone. Endocrinology 99:223-229.

Hiatt ES, Brunetta PG, Seiler GR, Barney SA, Selles WD, Wooledge $\mathrm{KH}$, King JC (1992) Subgroups of luteinizing hormone-releasing hormone pericarya defined by computer analyses in the basal forebrain of intact female rats. Endocrinology 130:1030-1043.

Hoffman GE, Lee WS, Attardi B, Yann V, Fitzsimmons D (1990) Luteinizing hormone-releasing hormone neurons express c-fos antigen after steroid activation. Endocrinology 126:1736-1741.

Jennes L, Stumpf WE (1986) Gonadotropin-releasing hormone immunoreactive neurons with access to fenestrated capillaries in mouse brain. Neuroscience 18:403-416.

Kalra SP, Kalra PS (1974) Temporal interrelationships among circulating levels of estradiol, progesterone and $\mathrm{LH}$ during the rat estrous cycle: effects of exogenous progesterone. Endocrinology 95:1711-1718.

Kalra SP, Kalra PS (1983) Neural regulation of luteinizing hormone secretion in the rat. Endocrinol Rev 4:311-351.

Kelly MJ, Garret J, Bosch MA, Roselli CE, Douglass J, Adelman JP, Ronnekliev OK (1989) Effects of ovariectomy on GnRH, proGnRH, and GnRH levels in the preoptic hypothalamus of the female rat. Neuroendocrinology 49:88-97.

Kim K, Ramirez VD (1982) In vitro progesterone stimulates the release of luteinizing hormone-releasing hormone from superfused hypothalamic tissue from ovariectomized estradiol-primed prepubertal rats. Endocrinology 111:750-757.

Kim K, Ramirez VD (1985) In vitro luteinizing hormone-releasing hormone release from superfused rat hypothalami: site of action of progesterone and effect of estrogen priming. Endocrinology 116:252258.

Kim K, Lee BJ, Park Y, Cho WK (1989) Progesterone increases mes- 
senger ribonucleic acid (mRNA) encoding luteinizing hormone releasing hormone (LHRH) level in the hypothalamus of ovariectomized estradiol-primed prepubertal rats. Mol Brain Res 6:151-158.

Knox KL, Schwartz NB (1992) RU486 blocks the secondary surge of follicle stimulating hormone in the rat without blocking the drop in serum inhibin. Biol Reprod 46:220-225.

Kobayashi RM, Lu KH, Moore RY, Yen SS (1978) Regional distribution of hypothalamic luteinizing hormone-releasing hormone in proestrous rats: effects of ovariectomy and estrogen replacement. Endocrinology 102:98-105.

Kornhauser JM, Nelson DE, Mayo KE, Takahashi JS (1990) Photic and circadian regulation of $\mathrm{c}$-fos gene expression in the hamster suprachiasmatic nucleus. Neuron 5:127-134.

Krey LC, Tyrey L, Everett JW (1973) The estrogen-induced advance in the cyclic LH surge in the rat: dependency on ovarian progesterone secretion. Endocrinology 93:385-390.

Lee W-S, Smith S, Hoffman GE (1990) Luteinizing hormone-releasing hormone neurons express fos protein during the proestrous surge of luteinizing hormone. Proc Natl Acad Sci USA 87:5163-5167.

Lee W-S, Abbud R, Smith MS, Hoffman GE (1992) LHRH neurons express c-jun protein during the proestrous surge of luteinizing hormone. Endocrinology 130:3101-3103.

Legan SJ, Karsch FJ (1975) A daily signal for the LH surge in the rat. Endocrinology 96:57-62.

Legan SJ, Coon GA, Karsch FJ (1975) Role of estrogen as initiator of daily LH surges in the ovariectomized rats. Endocrinology 96:5056.

Levine JE, Ramirez VD (1982) Luteinizing hormone-releasing hormone release during the rat estrous cycle and after ovariectomy as estimated with push-pull cannulae. Endocrinology 111:1439-1448.

Levine JE, Bauer-Dantoin AC, Besecke LM, Conaghan LA, Legan SJ, Meredith JM, Strobl FJ, Urban JH, Vogelsong KM, Wolfe AM (1991) Neuroendocrine regulation of luteinizing hormone-releasing hormone pulse generator in the rat. Recent Prog Horm Res 47:97-153.

Luderer U, Strobl FJ, Levine JE, Schwartz NB (1993) Differential gonadotropin responses to $N$-methyl-D,L-aspartate in metestrous, proestrous, and ovariectomized rats. Biol Reprod 48:857-866.

Malik KF, Silverman AJ, Morrell JI (1991) Gonadotropin-releasing hormone mRNA in the rat: distribution and neuronal content over the estrous cycle and after castration of males. Anat Rec 231:457466.

Marks DL, Smith MS, Vrontakis M, Clifton DK, Steiner RA (1993) Regulation of galanin gene expression in gonadotropin-releasing hormone neurons during the estrous cycle of the rat. Endocrinology 132: 1836-1844.

Mercenthaler I, Setalo G, Csontos C, Petrusz P, Flerko B, Negro-Vilar A (1989) Combined retrograde tracing and immunocytochemical identification of luteinizing hormone-releasing hormone- and somatostatin-containing neurons projecting to the median eminence of the rat. Endocrinology 125:2812-2821.

Mizunoma H, Samson WK, Lumpkin MD, McCann SM (1983) Purification of bioactive FSH-releasing factor (FSHRF). Brain Res Bull 10:623-629.

Neguin LG, Alvarez J, Schwartz NB (1979) Measurement of serum steroid and gonadotropin levels and uterine and ovarian variables throughout 4 day and 5 day estrous cycles in the rat. Biol Reprod 20: 659-670.

Park O-K, Gugneja S, Mayo KE (1990) Gonadotropin-releasing hormone gene expression during the rat estrous cycle: effects of pentobarbital and ovarian steroids. Endocrinology 127:365-372.

Parnet P, Lenoir V, Palkovits M, Kerdelhue B (1990) Estrous cycle variations in gonadotropin-releasing hormone, substance $P$ and betaendorphin contents in the median eminence, the arcuate nucleus and the medial preoptic nucleus in the rat: a detailed analysis of proestrus changes. J Neuroendocrinol 2:291-296.

Paxinos G, Watson C (1986) The rat brain in stereotaxic coordinates. San Diego: Academic.

Ramirez VD, Dluzen D, Lin D (1980) Progesterone administration in vivo stimulates release of luteinizing hormone-releasing hormone in vitro. Science 208:1037-1039.

Roberts JL, Dutlow CM, Jakubowski M, Blum M, Millar RP (1989) Estradiol stimulates preoptic area-anterior hypothalamic proGnRHGAP gene expression in ovariectomized rats. Mol Brain Res 6:127134.

Ronnekliev OK, Naylor BR, Bond CT, Adelman JP (1989) Combined immunohistochemistry for gonadotropin releasing hormone ( $\mathrm{GnRH}$ ) and pro-GnRH, and in situ hybridization for GnRH messenger ribonucleic acid in rat brain. Mol Endocrinol 3:363-371.

Rosie R, Thomson E, Fink G (1990) Oestrogen positive feedback stimulates the synthesis of LHRH mRNA in neurones of the rostral diencephalon of the rat. J Endocrinol 124:285-289.

Rothfeld J, Hejtmancik JF, Conn PM, Pfaff DW (1989) In situ hybridization for LHRH mRNA following estrogen treatment. Mol Brain Res 6:121-125.

Sarkar DK, Chiappa SA, Fink G (1976) Gonadotropin-releasing hormone surge in pro-oestrous rats. Nature 264:461-463.

Savoy-Moore RT, Schwartz NB, Duncan JA, Marshall JC (1980) Pituitary gonadotropin-releasing hormone receptors during the rat estrous cycle. Science 209:942-944.

Schwartz NB (1974) The role of FSH and LH and of their antibodies on follicle growth and on ovulation. Biol Reprod 10:236-272.

Silverman AJ, Jhamandas J, Renaud LP (1987) Localization of luteinizing hormone-releasing hormone (LHRH) neurons that project to the median eminence. J Neurosci 7:2312-2319.

Toranzo D, Dupont E, Simard J, Labrie C, Couet J, Labrie F, Pelletier $G$ (1989) Regulation of pro-gonadotropin-releasing hormone gene expression by sex steroids in the brain of male and female rats. Mol Endocrinol 3:1748-1756.

Turgeon JL, Waring DW (1981) Acute progesterone and 17beta-estradiol modulation of luteinizing hormone secretion by pituitaries of cycling rats superfused in vitro. Endocrinology 108:413-419.

Wise PM, Rance N, Selmanoff M, Barraclough CA (1981) Changes in radioimmunoassayable luteinizing hormone-releasing hormone in district brain areas of the rat at various times on proestrus, diestrus day 1 , and after pentobarbital administrations. Endocrinology 108 : 2179-2185.

Zoeller RT, Young WS (1988) Changes in cellular levels of messenger ribonucleic acid encoding gonadotropin-releasing hormone in the anterior hypothalamus of female rats during the estrus cycle. Endocrinology 123:1688-1689. 